\title{
The Effect of Auditors' Ethics on Their Detection of Creative Accounting Practices: A Field Study
}

\author{
Mohammed Abdullah Al Momani ${ }^{1}$ \& Mohammed Ibrahim Obeidat ${ }^{1}$ \\ ${ }^{1}$ Accounting Department, Jadara University, Irbid, Jordan \\ Correspondence: Mohammed Ibrahim Obeidat, Accounting Department, Jadara University, Irbid, Jordan. \\ E-mail: Leelas_2003@yahoo.com
}

Received: March 12, 2013

Accepted: March 29, 2013

Online Published: June 17, 2013

doi:10.5539/ijbm.v8n13p118

URL: http://dx.doi.org/10.5539/ijbm.v8n13p118

\begin{abstract}
The current study objects for investigating the effect of audit ethics on auditors' ability to detect the practices of creative accounting. In specific, it investigates the effect of auditor's independency, integrity, objectivity, contingent fees, advertising rights, commission determination, organization form, and name on auditors' ability to detect the practices of creative accounting. A sample consisting of 150 auditors had been selected based on the simple random sampling method among the total population of practicing auditors in Jordan. Simple linear regression method was used in testing the first three hypotheses, based on t-vale and the coefficient of significance, while multiple linear-regression method was used in testing the last hypothesis, based on f-value, and the coefficient of significance. The study finds that all of the above mentioned ethical rules affect auditors' ability to detect the practices of creative accounting.
\end{abstract}

Keywords: creative accounting, audit ethics, auditors' independency, integrity, advertising rights, contingent fees, organization form, commission determination

\section{Introduction}

Users of accounting information suffer these from different practices of creative accounting. These users require accurate, true, objective, faithful, and credible accounting information in order to be eligible to take good investment and credit decisions. Therefore, they need information that reflects the economics events that actually occurred during the accounting period. Moreover, they need information regarding the entire economic events. When the announced accounting information is subject to some practices of creative accounting, it will reduce users' ability to take good and beneficial decisions.

Over the recent two decades, several investors, stockholders, and creditors lost large amounts of money, because there decisions had been taken based on information that it was subject to different forms of creative accounting practices. As a result, a strong need emerged to restrict these practices, and to find the appropriate solutions for this problem.

Auditors add more credibility to financial information and financial statements. They can play an active role in reducing the effects of this problem. These auditors are qualified to detect these practices of creative accounting because they are supposed to have good knowledge regarding accounting and auditing professions. The questionable issue is not about the competence of auditors, but about their ethics. Some interested people believe that auditors' ethics are more important than their competence. They believe that when auditors follow the ethical rules of their profession, they will be able to play more important role in detecting the different methods of creative accounting practices, and they will be able to add enough solutions to this negative practice. Auditors are supposed to be well qualified to practice audit, and they have enough knowledge regarding the accounting principles and audit standards, but when they do not follow the ethics of their profession, they will not be able to provide any benefits to the audit profession as a whole, and they will not be able to provide the reasonable solutions for the problem of creative accounting. Because evidence was provided that the credit crunch has resulted in an increased risk of unethical behavior and fraud (Marx, 2009), we see that investigating the role of auditors' ethics in detecting the practices of creative accounting is an important issue.

The problem of the current study seems clear. The role of audit ethics in detecting and eliminating the practices of creative accounting is considered more important than auditors' competence, where most people believe that 
when auditors have the required competence, they can detect and eliminate these practices. Therefore, the role of auditors should be activated in order to be more effective in detecting and restricting the practices of creative accounting. The following question presents the problem of the study at a better form: Do the ethics of audit profession affect auditors' ability to detect the practices of creative accounting?

This study stems its importance from the harmful results that users face because some of their decisions have been taken based on inaccurate financial information. When financial statements are subject to creative accounting, the announced income may be more or less than its actual. In addition, creative accounting may lead to different values of assets and liabilities than the actual. The importance of the current study is increased when we determine the role that auditors able to play in detecting the practices of creative accounting. Furthermore, the ethical standards are important, so any profession will be unbeneficial when a large number of its practitioners do not follow the ethical standards of that profession. Several ethical standards or rules are available for any profession, whether these standards and rules are oral or written. Because it is important for auditors to follow the ethical standards of their profession, and because the avoidance of these standards is harmful for different groups of users, there are written ethical standards for auditing, called the Code of Professional Ethics.

The current study is also important because of the failure and accounting scandals of several large corporations such as Enron, Parmalat, HIH, and WorldCom, which have shaken investors' confidence in the transparency, integrity, and accountability of corporations and capital markets around the world. In addition, the public confidence regarding the role of auditors and audit firms have been declined as a result of these failure cases. These examples of collapse highlight the important role that auditors can play in detecting the practices of creative accounting. In addition, several economic and social results of these examples of failure occurred. Public consider that managements, directors, accountants, and audit firms are all responsible. Unscrupulous managements and boards of directors, in addition to accounting profession, and auditors, are all considered factors played an $\mathrm{f}$ important in the failure of these firms.

The study objects for to:

- Add more literature regarding the role of audit ethics in detecting and eliminating the practices of creative accounting.

- Show the effect of auditors' independency on their detection and eliminating of creative accounting practices.

- Show the effect of auditors' integrity and objectivity in detecting and eliminating the practices of creative accounting practices.

- Identify the role of auditors' contingent fees, rights of advertising, commission's determination, organization form and name, in detecting the practices of creative accounting.

The study differs from other prior researches. While most related prior researches investigated the role of auditors in detecting the practices of creative accounting, the current study focuses on the ethical aspects of the audit profession and its role in detecting creative accounting practices. In addition, some prior researches focused on the importance of auditors' competence and avoided the ethical issues, and do not investigate the role that audit ethics can play in restricting the practices of creative accounting.

The remaining of the study is structured to be as follows. Section 2 presents the related literature and prior researches of the study, followed by section 3, where the study hypotheses are presented. The followed methodology in the study is presented in section 4, while the results and analysis are presented in section 5 . Section 6 provides the findings and conclusions.

\section{Related Literature and Prior Researches}

Financial information involved in financial statements is important to investors, creditors, and other users of these statements. This information is considered the key source of data for users' investment, credit, and other decisions. To be beneficial for the purposes of decision making, accounting information should be characterized with several qualitative characteristics. Some of these characteristics are primary, such as relevance and reliability, while others are secondary, such as comparability and consistency (Kieso, Weygandt, and Warfield, 2007). Because managements are responsible for the reported financial statements, these managements may exercise some practices of creative accounting.

Users of accounting information require more credible data to take good investment and credit decisions. Creative accounting practices reduce the expected benefits of financial information, and may convert this 
information from useful to nonuseful information for the purposes of users' decisions. Therefore, these users may take ineffective and inefficient decisions because they depended on manipulated accounting information. As a result, users will be unable to achieve their investment, credit, and other objectives.

Auditors provide users of financial statements with more trust, faith, and credibility, because they have the right to depend on credible information and to be sure that the financial statements had been prepared based on the Generally Accepted Accounting Principles (GAAP), and these statements represent the actual events occurred during the accounting period.

\subsection{Creative Accounting}

Creative accounting is not a new phenomenon. The practices of creative accounting started since the industrial revolution and continued up to these days, but these practices increased since the starting of 1980 s of the previous century. As a result of the practices of creative accounting, several large firms failed and closed over the world.

Several terms appeared to express the effect of management on the amounts of items included in the financial statements. Those terms are: accounting manipulation, fraudulent reporting, income smoothing, earnings management, and creative accounting.

Rosner (2003), mentioned that accounting manipulation and fraudulent are two similar terms that represent management intent to interfere the measurement and disclosure of accounting transactions and items of the financial statements, even though the accounting standards do not permit these practices. Rosner also mentioned that earnings manipulation is a studied selection methods of the operating, financing, and investing operations. Moreover, he mentioned that such selection of accounting methods and policies is permitted by accounting standards, so this selection should be disclosed to users. Bolkaoui (2004), mentioned that creative accounting is the process of converting accounting numbers from its actual value toward a desired value by management, whereas, income smoothing is an intended smoothing of the announced number of income by management in order to decrease the variations in income from period to period, therefore, income appears at its normal amount.

Amat, Blake, and Dowds (1999), defined Creative accounting as "'a process whereby accountants use their knowledge of accounting rules to manipulate the reported figures in the accounts of a business organization. Naser (1993), defined creative accounting in a different way. He defined this term as "the transformation of financial accounting figures from what they actually are, to what preparer's desire, by taking advantage of the existing rules and/or ignoring some or all of them. It is apparent that there are several common elements in these three definitions. First, all authors of the above definitions find that the practices of creative accounting are undesirable, whatever the incentives or reasons of these practices. Second, creative accounting is perceived as a transformation from actual to inactual announced information. Based on these definitions, we see that creative accounting is a process where management attempts to transform actual financial information to incorrect information in order to satisfy the objectives of managements.

The questionable issue is why and how managements may practice creative accounting. Financial statements are a summary of all events that occurred in a particular firm during an accounting period. These statements are supposed to be prepared based on the GAAP. The GAAP determine contents, items, order, form, measurement methods, and the time of recognition. Managements of firms are responsible for the preparation and for the contents of these statements through its determination of the accounting methods and procedures that accountants of firms can use to prepare these statements. Managements of some firms attempt to practice what is called creative accounting.

Sometimes, managements may exploit the available high degree of flexibility in the accounting standards, such as the selection among the available methods of depreciation in determining the annual depreciation expense in order to reduce the total amount of expenses, and therefore, increase the amount of income. The selection among the available methods of inventory valuation sometimes appears appropriate by some management to increase inventory, so overvalued inventory leads to higher amount of income. Copeland, (1968) mentioned that income smoothing is a repetitive selection of accounting measures or estimations rules in a considerable manner in order to avoid the fluctuations of income from period to period, and managements can affect accounting numbers under the following constraints:

- $\quad$ No future obligations will appear on the firm during the future.

- $\quad$ The effect of management should not violate the GAAP.

- That effect should make a physical deviation in income from period to period. 
- The effect should not require actual transactions with external parties, but just reclassifying accounts balances inside the firm.

- Methods and tools of effect that are used separately or through the connection with other practices along the accounting periods.

Several methods can be followed to practice creative accounting, all of which can be categorized into the following four groups. (Amat, Blake, and Dowds (1999):

1) The selection among different available accounting methods.

2) The existence of estimation, judgment, and prediction in the financial statements.

3) The artificial transaction that can be made to manipulate the amounts of the balance sheet or move profits between the accounting periods.

4) The genuine transactions which can be timed to express the desired impression in the accounts.

The question is why managements may exercise creative accounting? Actually, there are several reasons may promote managements to practice the issue of creative accounting, among these are: (Amat, Blake, and Dowds, 1999).

1) Income smoothing. Managements may prefer to announce a steady trend of growth in profit and attempt to announce a volatile profits from period to period.

2) Forecasts satisfying. Managements may sometimes exercise creative accounting in order to tie its profits into the forecasts of financial analysts and other interested people.

3) Attention distraction from bad news. Managements may practice creative accounting to keep an income-boosting policy change in its hands.

4) Influence of market-share price. Managements may practice creative accounting to maintain its current market-share price through the appearance of good profits or through reducing the appearance level of its borrowings.

5) Enhancing the benefits of inside knowledge.

\subsection{Audit Ethics}

Several ethical patterns should be followed when each profession is practiced, whatever the nature, or type of that profession. When many practitioners of a particular profession do not follow the ethics of their profession, that profession loses its importance and usefulness to the society as a whole. Auditing is an important profession for most societies. Audit profession provides several services, such as assurance, attestation, review of historical financial statements, and other attestation services (Arens, 2010). In other words, auditors provide users of financial statements with more confidence that the available information in financial statements had been reported based on the GAAP, and have enough degree of objectivity and faithfulness.

The code of professional ethics for the audit profession provides both general standards of ideal conduct and specific enforceable rules of conduct. This code consists of four parts including, (1) Principles, (2) rules of conduct, (3) interpretations of the rules of conduct, and (4) ethical ruling.

Principles involved in the code of professional conduct for the profession of audit are ideal standards of ethical conduct stated in philosophical terms. These principles are unenforceable, and are as follows (Arens, 2010):

1) Responsibilities. Auditors have to exercise sensitive professional and moral judgment while they carry out their responsibilities.

2) Public interest. Auditors have to practice their activities in a way that will serve the public interest, honor the public interest, and demonstrate commitment to profession.

3) Integrity. Auditors should perform all of their professional responsibilities at the highest possible sense of integrity.

4) Due care. Auditors should observe the profession's technical and ethical standards and strive to improve their competences and the quality of their services.

5) Scope and nature of services. Auditors in practice should observe the principles of the code of professional conduct while they determine the scope and nature of cervices that they are required to provide.

Rules of conduct are minimum standards of ethical conduct stated as specific rules. All of these rules are enforceable. An auditor in practice should be independent, and shall not disclose any confidential client 
information without the specific consent of the client, with some exceptions in specific situations. Moreover, an auditor in practice shall not perform for a contingent fee any professional services if he/she also performs for the same client an audit, review, certain compilation for financial statements, or an examination of prospective financial statements. In addition, an auditor in practice is prohibited from advertising or other forms of solicitation in a false, misleading, or deceptive manner, solicitation by the use of coercion, overreaching, or harassing conduct. Among the enforceable rules of auditors in practice is that auditors are prohibited from the receipt or payment of a commission or referral fees for any client if the auditor also performs for the same client an audit, review, or certain compilation of financial statements, or an examination of prospective financial statements. The last enforceable rule in the code of professional conduct is that an auditor may practice his profession in a form of organization permitted by the country, and is not permitted to practice the profession under a misleading firm name.

Interpretations of the rule of conduct are issued by the Division of Professional Ethics in the American Institute of Certified Public Accountants (AICPA). These interpretations are unenforceable, but a departure from these interpretations should be justified, despite that this departure is difficult, if not impossible. The need for these interpretations arises when there are frequent questions from practitioners regarding a particular issue.

Ethical rulings are published explanations and answers for questions regarding rules of conduct. These explanations and answers are submitted to the AICPA by practitioners and other interested people in ethical requirements. Explanations and answers underline the ethical ruling are issued by the executive committee of the professional ethics division.

Due to the ethics of auditors, and as a result of failure of several large corporations such as Enron, Parmalat, and WorldCom, the public confidence regarding the role of auditors and audit firms have been weakened, because auditors of these corporations are responsible for these failures. Moreover, most users and other interested people believe that auditors are responsible because they neglected the ethics of their profession, despite they have high competence.

\subsection{Prior Researches}

Regarding the role of auditors' ethics in detecting the practices of creative accounting, the failures occurred during the recent twenty years, have again highlighted the gap between public expectations and the reality of auditors' role. Public perceive that auditor should have acted as a control on unscrupulous management practices, especially in the case of Enron. Moreover, public agree that auditors failed in this responsibility because their independence from the management of Enron was compromised. The profession of audit should acknowledge and address these types of perceptions, or indeed facts, if it is to restore trust in both the capital markets and itself.

The most important challenge encounters auditors these days, is to identify how ethical behavior can be restored. This issue should be the basis for the reconstruction of public trust in the profession of auditing.

Even though the issue of creative accounting had been given enough attention in the Northern and Far-East countries, the issue had not been given the deserved attention in most of Arab countries. The appearance of the recent international financial crisis that emerged during the second half of 2008 should encourage academics, researchers, and other interested people, to investigate the role of auditors' ethics on the crisis occurrence, especially because some Arab countries had been strongly affected by that crisis.

Marx, (2009) investigated the effect of credit crunch on the evolving responsibilities of the modern audit-committee. He provided the evidence that credit crunch has resulted in an increased risk of unethical behavior and fraud, as well as a growing need for ethics to be responsible corporate citizens. It was argued that the audit-committee as a subcommittee of the board of directors is well placed to deal ethics and substantially issues of the boards' behalf. The study provided the evidence that the audit-committees are already dealing with ethical and sustainability issues among the behalf of the boards. The study finds that only 47.2 percent are currently reviewing their company's sustainability reports, and recommends that audit-committees should oversee the companies' stakeholder reporting.

Rabin, (2003) studied the determinants of auditors' attitudes towards creative accounting. In more details, the author of this study investigates whether there is association between auditors' attitudes towards creative accounting and their ethical judgment. In addition, the author also investigates the association between auditors' attitudes and their evaluation of the quality of financial reporting and their perception of factors that influence preparers of financial statements to use aggressive accounting techniques. The study finds that a significant relationship exists between auditors' assessment of the relevance and reliability of reported information and their 
attitudes towards creative accounting. Moreover, the study gained some insight into auditors' perceptions of the factors that influence preparers for the use of creative accounting in South Africa.

Marianne, (2006) carried out a study to determine the importance of audit independence to the external auditors' role in banking regulation and supervision. In addition, the study investigates the factors which may threaten auditors' independence. The study finds that despite the support of the dual role of the reporting accountants and external auditors, independency of auditors is still questionable because both roles of auditor and reporting accountant are separate and the external auditor perform a non-audit services. As a result, more safeguards should be in place in relation to the dual role of the external auditor and reporting accountant, and more alternatives should be provided before the role of reporting accountant is taken as means of last resort. Moreover, the study reveals that mandatory rotation of auditors may be detrimental, and a cost-benefit analysis of this mandatory rotation is necessary before the decision to implement, or not, is taken. In addition, the study reveals that auditors should be held more accountable for negative consequences of their actions towards the third party. At end, the study recommends more works to be carried regarding audit liability.

Moldovan, Achim, and Avram, (2010) studied the role of creative accounting as a technique of accounts manipulation in contrast with the fair view presentation, and the ethics of accounting profession. In this study, the authors reviewed the opinions of different authors on the subject while contrasting both fraud and professional ethics with creative accounting. In addition, they explained the inverse casual relationship between creative accounting and fair view principle. The study reviewed the writings of other authors regarding creative account in order to find or recommend some solutions to this problem which threaten the fair presentation. The recommended solutions in this area are related to accounting rules and professional accounting ethics. These solutions are characterized with its practicability and can be put in practice by the company itself and by other interested users.

Vladu, and Matis, (2010) carried out a study regarding the connection between corporate governance and creative accounting. The author states that corporate governance is concerned with the relationship between a business's management and its board of directors, shareholders and lenders and stakeholders such as employees, customers, suppliers, and the community in which activates. The study offers interesting insights in to this connection by examining the previous developed relevant ideas in the process of understanding, reinforcing, and rediscovering this association. By conducting this study, the author wanted to reinforce the role of literature analysts as an interpreter.

Matar and Al Halabi, (2009) investigated the role that auditors can play in restricting creative accounting and its effect on the reliability of accounting information. The purpose of the study is to identify the used methods in creative accounting practices and its effects on the reliability of accounting information, and to determine management's incentives behind its exercise to these practices. Other important goal of the study are to identify the role that auditors play in detecting and restricting the practices of creative accounting that occurred by the shareholding Jordanian companies. The study finds that the followed methods in practicing creative accounting affect the reliability of announced accounting information by the above mentioned type of Jordanian companies. In addition, the study finds that management practice different methods to exercise creative accounting, but auditors take the required procedures and tests to detect these practices.

Dahdouh, (2006) carried out a related study to the subject of creative accounting and the role of auditors in this issue. The study objects for determining the problem of fraudulent in financial statements, and to identify the factors that determine its detection following to failure in several large corporations all over the world. The study focused on the role of auditors in detecting fraudulent practices in Jordan. He finds that there are several factors associated with auditors, and other factors associated with the firm, can help in detecting fraudulent in financial statements. The most important conclusion of the study is that auditors' ability in detecting fraudulent in financial statements is influenced by different associated factors with the issuances of these companies.

Cormier and Lapointe, (2006) investigated auditors' assessment and detection of corporate fraud. The main objective of the study was to examine and assess the ability of auditors to detect fraud in accounting data, under a free environment of audit standards that does not enforce auditors to take the details and test of fraud detection in Canada. In addition, the study investigated the role that auditors can play in fraud detection and the procedures that they can take to reduce such cases. The study finds that auditors are more interested with the factors of fraud risk which associated with fraud over audit steps. Auditors estimate the factors of fraud risk through there focus on the primary analysis, where they have more ability to detect fraud. They also use determined procedures of analysis to detect fraud in each of audit steps. 


\section{Research Hypotheses}

Based on the literature review and prior researches, the following hypotheses had been developed in their null form:

1) Auditors' independency does not affect their ability to detect the practices of creative accounting.

2) Auditors' integrity and objectivity do not affect their ability to detect the practices of creative accounting.

3) Auditors' ethical rules of contingent fees, rights of advertising, commissions determination, and the use of organization form and name do not affect auditors' ability to detect the practices of creative accounting.

4) All ethical aspects of audit profession do not affect auditors' ability to detect creative accounting practices.

\section{Methodology}

All auditors in practice in Jordan constitute the study population, while a sample consisting of 150 auditors in practice was selected among the entire population which includes 623 auditors, based on the simple random sampling method. A questionnaire consisting of four sections had been developed and self-administered to respondents. The first section was designed to collect the related demographic data regarding respondents. This section consists of 5 items including; age, experience, gender, position, and qualifications. Auditors' ability to detect creative accounting practices were measured through the second section which consists of 25 items. Because independency is an important ethical issue for auditors, the third section is consisting of 16 items; all of which were used to measure auditors' independency. Integrity and objectivity are also two important overlapped ethical rules. Therefore, the fourth section was developed to measure these tow important ethical requirements to auditors in practice. Additional ethical issues to practicing auditors were grouped in the fifth section. These additional issues are contingent fees, rights of advertising, commission determination, and the use of organization form and name.

The questionnaire had been designed and administered for respondents in Arabic, and translated back to English, because most respondents have more ability to understand Arabic better than English. In additions, a group of academics and auditors of long year-experience received the questionnaire after its primary development and before its distribution to respondents, for more comments, notes, or recommendations. All provided notes and comments by this group of academics and auditors had been taken with consideration, and reflected in the final questionnaire.

Using the Statistical Package of Social Studies (SPSS), different statistical methods had been used in the data analysis and in the hypotheses testing. Descriptive statistics were used to describe the demographic data of respondents. In addition, simple-linear regression method was used to test the first three hypotheses, based on $\mathrm{t}$-test, while the multiple-linear regression method was used to test the fourth one, based on f-test. Based on the regression method, the model of the study is as follows:

$$
C A D=a+b I+c O+d D R+e
$$

Where:
$C A D$
The ability of creative accounting detection
$I$ Independency
$O$ Integrity and objectivity
$D R \quad$ Other rules of creative accounting
$A, b$, and $c \quad$ Constants

All hypotheses were tested by using two different methods. The first is a comparison between the computed and the tabulated t-value which was used in testing the first three hypotheses, or a comparison between the computed and the tabulated $\mathrm{f}$-vale regarding the last hypothesis. The second method is a comparison between the computed and the predetermined coefficient of significance, which equals $(0.05)$ based on (0.95) level of confidence.

\section{Analysis and Results}

\subsection{Sample Description}

Based on the outputs acquired by using SPSS, table (1) shows the necessary information regarding the year-experience of respondents. The table shows that just 2.1 percent of respondents have less than 5 year-experience. In other words, 97.9 percent of these respondents have more than 5 year-experience. The table 
also shows that most respondents have 10 to 20 year-experience. This information is considered a strength for the study, because when a high percentage of respondents have long year-experience, they will be more able to understand and answer the items better than those who have lower year-experience.

Table 1. Number of experience-year of respondents

\begin{tabular}{llll}
\hline No. of Year Experience & Frequency & Percent & Cumulative Percent \\
\hline Less than 5 years & 3 & 2.1 & 2.1 \\
$5 \&$ less than 10 & 15 & 10.6 & 12.7 \\
10 and \$ than 15 & 56 & 39.4 & 52.1 \\
$15 \&$ less than 20 & 53 & 37.3 & 89.4 \\
10 and \$ than 15 & 15 & 10.6 & 100 \\
Total & 142 & 100 & \\
\hline
\end{tabular}

Regarding respondents' age, table 2 shows that 5.6 percent of respondents have less than 30 years old. In addition, the table shows that 57 (40.1 percent) of respondents have 40 and less than 50 years old. In brief, the table shows that 94.4 percent of respondents have 30 or more years old. This information regarding the age of respondents adds more credibility to the study, because when most respondents are old, their understandings and answers to the items of the questionnaire will be more accurate.

Table 2. Age of respondents

\begin{tabular}{llll}
\hline No. of Year Experience & Frequency & Percent & Cumulative Percent \\
\hline Less than 30 years & 8 & 5.6 & 5.6 \\
30 and less than 40 years & 28 & 19.7 & 25.4 \\
40 and less than 50 years & 57 & 40.1 & 65.5 \\
50 and less than 60 years & 35 & 24.6 & 90.1 \\
60 years and more & 14 & 9.9 & 100 \\
Total & 142 & 100 & \\
\hline
\end{tabular}

With regard to the positions the respondents occupy in their audit profession, table 3 shows that 67.6 percent of respondents practice audit profession as auditors in an audit team, while 9 of them are audit managers. In other words, more than two thirds of respondents exercise the audit profession in their day to day activities as auditors in a team. This information is also considered a point of strength for the study, because when most respondents exercise auditing in their day to day activities, they will be more able to understand the items of the questionnaire, and also will have more ability to provide more accurate answers for these items.

Table 3. Positions of respondents

\begin{tabular}{lccc}
\hline No. of Year Experience & Frequency & Percent & Cumulative Percent \\
\hline An audit manager & 9 & 6.3 & 6.3 \\
Team Leader & 24 & 16.9 & 23.2 \\
An auditor in an audit team & 96 & 67.6 & 90.8 \\
Other Position & 13 & 9.2 & 100 \\
Total & 142 & 100 & \\
\hline
\end{tabular}

Table 4 shows information regarding respondents' gender. Based on information appear in this table, most respondents are male, while only 11 respondents are female. Auditing is a field profession, so it is more appropriate to male people than female, especially in eastern countries, where Jordan is one among these countries. 
Table 4. Gender of respondents

\begin{tabular}{llll}
\hline No. of Year Experience & Frequency & Percent & Cumulative Percent \\
\hline An audit manager & 131 & 92.3 & 92.3 \\
Team Leader & 11 & 7.7 & 100 \\
Total & 142 & 100 & \\
\hline
\end{tabular}

Table 5 shows the education level of respondents. The table shows that 91.5 percent of respondents have the bachelor or higher degree, so only 8.5 percent of them have less than the bachelor. This peace of information is an advantage for the research because when most respondents have enough qualifications, they will have good ability to understand the items of the questionnaire, and have more ability to provide reasonable responses to these items.

Table 5. Education level of respondents

\begin{tabular}{llll}
\hline No. of Year Experience & Frequency & Percent & Cumulative Percent \\
\hline Lower than the bachelor degree & 12 & 8.5 & 8.5 \\
Bachelor degree & 108 & 76.1 & 84.5 \\
Master degree & 17 & 12 & 96.5 \\
Higher than master degree & 5 & 3.5 & 100 \\
Total & 142 & 100 & \\
\hline
\end{tabular}

\subsection{Hypotheses Testing}

It was mentioned in previous location that single-linear regression method is used in testing the first three hypotheses based on t-vale under 95 percent level of confidence, while multiple-linear regression method is used in testing the last hypothesis based on $\mathrm{f}$-value and under the same level of confidence that used in testing the first three hypotheses.

\subsubsection{The First Hypothesis}

The first hypothesis deals with the effect of auditors' independency, and had been presented as follows.

\section{Auditors' independency does not affect their ability to detect the practices of creative accounting.}

The first section of the questionnaire consists of 25 items, and used to measure the ability of auditors to detect the practices of creative accounting. These items are shown in table 6, in addition to the mean and standard deviation of each item. Considering the table, it is apparent that all means are between 3 and 4 , while most standard deviations are around 1. The highest mean equals 3.782, and attributed to item 12, which states that "I am able to detect any manipulation in provisions" whereas the lowest one equal 3.063, and attributed to item number 3, which states that "I believe that I am able to detect the sale of an asset and lease it again to increase profits". The highest standard deviation equals 1.4035 , and belongs to item number 20 , which states that "I think that I can detect that managements recognized uninsured litigations", while the lowest one equals 0.809 , and belongs to item 15 , which states that "Auditors have the abilities to identify that disclosure do not cover some events".

Table 6. Descriptive statistics of the used items in measuring creative accounting

\begin{tabular}{clcc}
\hline Ser. No. & \multicolumn{1}{c}{ The Item } & Mean & $\begin{array}{c}\text { Standard } \\
\text { Deviation }\end{array}$ \\
\hline 1. & $\quad \begin{array}{l}\text { I feel that I am able to detect the sale of assets at higher prices than its book value in a } \\
\text { selected periods, just to affect the client's profits }\end{array}$ & 3.535 & 1.093 \\
& I feel that I am able to detect the artificial entries to affect profits in selected accounting & 3.472 & 0.881 \\
2. & periods. & 3.063 & 0.885 \\
3. & I believe that I am able to detect the sale of an asset and lease it again to increase profits & 3.366 & 0.934 \\
4. & I feel that I am able to identify any transfer of profits from period to period. & 3.465 & 1.001 \\
5. & I perceive that managements have incentives to practice creative accounting. & 0.912 \\
6. & I feel that I have the abilities to detect the transfer of transactions from period to period. & 3.549 & \\
\hline
\end{tabular}




\begin{tabular}{|c|c|c|c|}
\hline 7. & $\begin{array}{l}\text { I think that I have the abilities to detect the selection of a selected accounting method to } \\
\text { maximize profits. }\end{array}$ & 3.718 & 0.985 \\
\hline 8. & I perceive that managements have several incentives to manipulate its revenues. & 3.628 & 1.056 \\
\hline 9. & $\begin{array}{l}\text { I have the ability to detect the creative accounting procedures that have been taken to } \\
\text { capitalize noncapitalizable expenses. }\end{array}$ & 3.578 & 1.094 \\
\hline 10. & I perceive that managements may record nonfactual revenues & 3.380 & 1.096 \\
\hline 11. & I am able to detect any overvalued inventory. & 3.486 & 1.096 \\
\hline 12. & I am able to detect any manipulation of provisions. & 3.782 & 1.105 \\
\hline 13. & I perceive any undervalued bad debts. & 3.549 & 0.979 \\
\hline 14. & I can detect that managements did not record any decrease in the prices of assets. & 3.394 & 0.825 \\
\hline 15. & Auditors have the abilities to identify that disclosure do not cover some events. & 3.352 & 0.809 \\
\hline 16. & Auditors can detect any overvalued intangible assets. & 3.289 & 0.912 \\
\hline 17. & $\begin{array}{l}\text { I think that I can detect that the client did not apply the principle of historical cost where } \\
\text { it should be used. }\end{array}$ & 3.3883 & 1.084 \\
\hline 18. & $\begin{array}{l}\text { I have the required ability to identify that the management did not disclose the items of } \\
\text { restricted cash. }\end{array}$ & 3.296 & 0.840 \\
\hline 19. & I can detect any change in the used accounting methods of long-term investments & 3.479 & 1.043 \\
\hline 20. & I think that I can detect that managements recognized uninsured litigations. & 3.557 & 1.4035 \\
\hline 21. & $\begin{array}{l}\text { I can detect that the management does not classify the payable part of long-term loans } \\
\text { under short-term loans. }\end{array}$ & 3.479 & 1.090 \\
\hline 22. & I can detect that revenue is recognized while the sale transaction is still incomplete. & 3.437 & 1.107 \\
\hline 23. & $\begin{array}{l}\text { I perceive that managements have the incentives to transfer a specific expense from a } \\
\text { current to future period. }\end{array}$ & 3.597 & 1.092 \\
\hline 24. & $\begin{array}{l}\text { I perceive that managements may classify some operating cash flows under investing or } \\
\text { financing activities. }\end{array}$ & 3.690 & 1.143 \\
\hline 25. & I perceive that managements may remove a nonrecurring item. & 3.430 & 0.933 \\
\hline
\end{tabular}

The second section of the questionnaire includes 17 items, all of which were used to measure auditors' independency. Table 7 shows these items in addition to the mean and standard deviation of each one. The table reveals that all items have a reasonable mean and standard deviation, so there are no extremes in these means and standard deviations. The table also shows that item number 17, which states that "I am able to maintain an unbiased attitude throughout the audit in practice" has the highest mean, while item number 13, which states that "I don't audit statements of a client when my family has financial interests in that client" has the lowest one. The highest mean equals 4.007 , while the lowest one equals 3.416. The highest standard deviation equals 1.247 , and belongs to item number 10, whereas the lowest one equals 0.987 , and due to item number 6 .

Table 7. Descriptive statistics for items used in measuring independency

\begin{tabular}{|c|c|c|c|}
\hline Ser. No. & The Item & Mean & $\begin{array}{l}\text { Standard } \\
\text { Deviation }\end{array}$ \\
\hline 1. & I think that I am independent in fact while I am practicing my audit profession. & 3.887 & 1.161 \\
\hline 2. & I think that I am independent in appearance while I am practicing my audit profession. & 3.648 & 1.012 \\
\hline 3. & $\begin{array}{l}\text { I think that I am independent while I am practicing my professional services as required by } \\
\text { the audit standards. }\end{array}$ & 3.894 & 1.050 \\
\hline 4. & I believe that users of accounting information perceive that I am independent. & 3.831 & 1.098 \\
\hline 5. & I have unbiased viewpoints when I issue my audit reports. & 3.985 & 0.975 \\
\hline 6. & I have unbiased viewpoints while I am evaluating the results of audit. & 3.768 & 0.987 \\
\hline 7. & I exercise my duties in a sensitive professional manner & 4.000 & 1.004 \\
\hline 8. & I have unbiased viewpoints while I am performing the audit test. & 3.965 & 1.107 \\
\hline 9. & $\begin{array}{l}\text { I refuse to audit the financial statements of a client that there is a lawsuit or intent for a } \\
\text { lawsuit to start between me and a client. }\end{array}$ & 3.606 & 1.179 \\
\hline 10. & $\begin{array}{l}\text { I don't perform audit activities for a client that I am a director, officer, manager, or } \\
\text { employee in the client firm. }\end{array}$ & 3.817 & 1.247 \\
\hline 11. & $\begin{array}{l}\text { I don't accept the performance of audit duties for a client that I have an ownership of joint } \\
\text { investor or investee relations with that client. }\end{array}$ & 3.711 & 1.170 \\
\hline
\end{tabular}




\begin{tabular}{|c|c|c|c|}
\hline 12. & I don't audit the statements of a client that I have loans from the client 's firm. & 3.852 & 1.220 \\
\hline 13. & I don't audit statements of a client when my family has financial interests in that client. & 3.416 & 1.256 \\
\hline 14. & $\begin{array}{l}\text { I don't audit the statements of a client that I have material indirect investments in that } \\
\text { client. }\end{array}$ & 3.394 & .952 \\
\hline 15. & $\begin{array}{l}\text { I do not accept the audit of a client's statements when I have some financial interests in that } \\
\text { client. }\end{array}$ & 3.648 & 1.198 \\
\hline 16. & I don't accept to audit the client's statements when I have stocks in that client. & 3.775 & 1.205 \\
\hline 17. & I am able to maintain an unbiased attitude throughout the audit in practice. & 4.007 & 1.133 \\
\hline
\end{tabular}

Table 8 presents more statistics regarding the effect of auditors' independency on detecting and restricting creative accounting practices. It shows t-value, degrees of freedom, coefficient of correlation (R), coefficient of determination $\left(\mathrm{R}^{2}\right)$, and the level of significance for the entire group of items. The table shows that the computed $\mathrm{t}$-value equals 2.74 , and the computed coefficient of significance equals 0.007 . When the computed $t$-value is compared with the tabulated one, which equals 1.96, it is apparent that the computed one is greater than the tabulated. Because the computed t-value is greater than the tabulated, the null hypothesis is rejected, while the alternative one is accepted. In other words, the test of this hypothesis means that auditors' independency affects their ability to detect the practices of creative accounting. Regarding the coefficient of correlation, and the coefficient of determination, the table shows that $r$ equals 0.226 , while $r^{2}$ equals 0.051 , which means that a weak correlation is available between auditors independency and their ability to detect the practices of creative accounting, and independency interprets only 0.055 of the change occurring in auditors ability to detect creative accounting practices.

Based on statistics appear in table 8, the regression model regarding the effect of auditors' independency on their ability to detect the practices of creative accounting is as follows:

$$
C A D=68.36+4.924 I+e
$$

Table 8. Related statistics to the effect of auditors independency on auditors' ability to detect creative accounting practices

\begin{tabular}{llllll}
\hline T-value & $\mathbf{R}$ & $\mathbf{R}^{2}$ & Degrees of Freedom & B & Significance \\
\hline 2.74 & 0.226 & 0.051 & 141 & 4.924 & 0.007 \\
\hline
\end{tabular}

\subsubsection{The Second Hypothesis}

The second hypothesis is developed to deal with the effect of auditors' objectivity and integrity on their ability to detect the practices of creative accounting. Therefore the second hypothesis is stated as follows:

\section{Auditors' integrity and objectivity do not affect their ability to detect the practices of creative accounting.}

The third section of the questionnaire encompasses 11 items, all of which were used to measure auditors' integrity and objectivity. These two ethical rules were measured together because it is difficult to separate each rule from the other. Table 9 shows the statistics of these items. Specifically, the table shows the mean and the standard deviation for each included item in the group. The table reveals that all items have a reasonable means and standard deviations, so there are no extremes in these means and standard deviations. The table also shows that item number 2, which states that "I am free of conflict of interests while I am performing my audit duties", has the highest mean, while item number 10, which states that "I attempt to maintain integrity in all of my duties", has the lowest one. The highest mean equals 3.789, while the lowest one equals 3.247. The highest standard deviation equals 1.168 , and belongs to item number 10 , whereas the lowest one equals 0.886 , and due to item number 8 . 
Table 9. Descriptive Statistics of the used items in measuring the Auditors' Integrity and objectivity

\begin{tabular}{clll}
\hline Ser. No. & \multicolumn{1}{c}{ The Item } & Mean & $\begin{array}{c}\text { Standard } \\
\text { Deviation }\end{array}$ \\
\hline 1. & I maintain integrity while I am performing my audit duties. & 3.669 & 1.030 \\
2. & I am free of conflict of interests while I am performing my audit duties. & 3.789 & 1.051 \\
3. & I don't knowingly misrepresent facts or subordinate my judgment to others while I am & 3.662 & 1.024 \\
& performing my audit duties. & 3.775 & 0.970 \\
4. & I attempt to be objective while I am practicing my audit duties. & 3.768 & 1.089 \\
5. & I feel that I am free of conflict of interest in discharging my professional responsibilities & 3.690 & 0.932 \\
6. & I perform my professional responsibilities with the highest sense of integrity & 3.761 & 1.010 \\
7. & I attempt to maintain objectivity in all of my duties. & 3.768 & 0.886 \\
8. & I am able to take unbiased viewpoint in the performance of my audit. & 3.599 & 1.045 \\
9. & I feel that I am in practice able to take unbiased viewpoint in the evaluation of results. & 3.247 & 1.168 \\
10. & I attempt to maintain integrity in all of my duties. & 3.493 & 1.037 \\
11. & I am free of conflict of interests & & \\
\hline
\end{tabular}

Table 10 presents the related statistics regarding the effect of auditors' objectivity and integrity on their ability to detect and restrict the practices of creative accounting phenomenon. In specific, it shows t-value, degrees of freedom, coefficient of correlation (R), coefficient of determination $\left(R^{2}\right)$, and the level of significance for the entire group of items. The table shows that the computed t-value equals 3.039, and the computed coefficient of significance equals 0.003 . When the computed t-value is compared with the tabulated one, which equals 1.96 , it is apparent that the computed one is greater. Moreover, when the computed coefficient of significance is compared with the predetermined one, which equals 0.05 (1- 0.95), it is clear that the computed one is lower. Because the computed t-value is greater than the tabulated, and the computed coefficient of significance is lower than the predetermined one, the null hypothesis is rejected, and the alternative one is accepted. In other words the test reveals that auditors' ability to detect the practices of creative accounting is influenced by their objectivity and integrity. Regarding the coefficients of correlation and determination, the table shows that $\mathrm{r}$ equals 0.249 and $r^{2}$ equals 0062 , which means a weak correlation exists between integrity and objectivity in one side, and auditors' ability to detect the practices of correlation in the other side.

Table 10. Related statistics to the effect of auditors integrity and objectivity on auditors' ability to detect creative accounting practices

\begin{tabular}{cccccc}
\hline T-value & $\mathbf{R}$ & $\mathbf{R}^{\mathbf{2}}$ & Degrees of Freedom & B & Significance \\
\hline 3.039 & 0.249 & 0.062 & 141 & 5.523 & 0.003 \\
\hline
\end{tabular}

Based on the available statistics in table 10, the regression model is as follows:

$$
C A D=68.36+4.924 I+e
$$

\subsubsection{The Third Hypothesis}

This hypothesis takes into consideration the effect of different less important ethical rules on the practices of creative accounting practices. Therefore, the hypothesis is presented as follows:

\section{Auditors' ethical rules of contingent fees, rights of advertising, commissions determination, and the use of organization form and name do not affect auditors' abilities to detect the practices of creative accounting.}

The fourth section of the questionnaire includes 12 items, all of which were used to measure the effect of auditors' other ethical rules including contingent fees, rights of advertising, commission determination, and organization form and name on the phenomenon of creative accounting practices. These ethical rules were grouped in one section because they are less important than independency, objectivity, and integrity. Table 11 shows the mean and the standard deviation of each of these items. It shows that all items have a moderate mean and standard deviation, so there are no extremes among these means and standard deviations. The table also shows that item number 12, which states that "When I am in practice, I don't receive or pay a commission or referral fee for any client if I perform for that client a review, or certain compilation of financial statements", has 
the highest mean, while item number 4, which states that "When I am in public practice, I don't perform for a contingent fee any professional services if I perform for the same client an examination of prospective financial statements". The highest mean equals 3.690, while the lowest one equals 3.176. The highest standard deviation equals 1.080 and belongs to item number 9 , whereas the lowest one equals 0.782 , and due to item number 8 .

Table 11. Descriptive statistics of the used items in measuring the audit ethical values of contingent fees, rights of advertising, organization form, and name

\begin{tabular}{|c|c|c|c|}
\hline Ser. No. & The Item & Mean & $\begin{array}{l}\text { Standard } \\
\text { Deviation }\end{array}$ \\
\hline 1. & $\begin{array}{l}\text { When I am in public practice, I don't perform for a contingent fee any professional } \\
\text { services if I perform for the same client audit activities. }\end{array}$ & 3.430 & .933 \\
\hline 2. & $\begin{array}{l}\text { When I am in public practice, I don't perform for a contingent fee, any professional } \\
\text { services if I perform for the same client a review. }\end{array}$ & 3.296 & .823 \\
\hline 3. & $\begin{array}{l}\text { When I am in public practice, I don't perform for a contingent fee any professional } \\
\text { services if I perform for the same client certain compilation of financial statements. }\end{array}$ & 3.218 & .782 \\
\hline 4. & $\begin{array}{l}\text { When I am in public practice, I don't perform for a contingent fee any professional } \\
\text { services if I perform for the same client an examination of prospective financial } \\
\text { statements. }\end{array}$ & 3.176 & .886 \\
\hline 5. & $\begin{array}{l}\text { When I am in practice, I don't seek to obtain clients by advertising and other forms of } \\
\text { solicitation in a false manner. }\end{array}$ & 3.542 & .987 \\
\hline 6. & $\begin{array}{l}\text { When I am in practice, I don't seek to obtain clients by other forms of solicitation in a } \\
\text { misleading manner. }\end{array}$ & 3.394 & .816 \\
\hline 7. & $\begin{array}{l}\text { When I am in practice, I don't seek to obtain clients by advertising and other forms of } \\
\text { solicitation in a deceptive manner. }\end{array}$ & 3.606 & 1.003 \\
\hline 8. & $\begin{array}{l}\text { When I am in practice, I don't receive or pay a commission or referral fee for any client if I } \\
\text { perform for the client an audit. }\end{array}$ & 3.500 & 1.050 \\
\hline 9. & $\begin{array}{l}\text { When I am in practice, I don't receive or pay a commission or referral fee for any client if I } \\
\text { perform for the client a review, or certain compilation of financial statements. }\end{array}$ & 3.479 & 1.090 \\
\hline 10. & $\begin{array}{l}\text { When I am in practice, I don't receive or pay a commission or referral fee for any client if I } \\
\text { perform for the client an examination of prospective financial statements. }\end{array}$ & 3.437 & 1.107 \\
\hline 11. & When I am in practice, I perform my profession in an allowed form of organization. & 3.599 & 1.092 \\
\hline 12. & When I am in practice, I don't practice public accounting under a misleading name. & 3.690 & 1.143 \\
\hline
\end{tabular}

Table 12 shows more statistics regarding the contingent fees, commission determination, rights of advertising, and organization form and name. In specific, it shows t-value, degrees of freedom, coefficient of correlation (R), coefficient of determination $\left(\mathrm{R}^{2}\right)$, and the level of significance for the entire group of items. The table reveals that the computed t-value equals 97.177 , and the computed coefficient of significance equals zero, or a much closed value to zero. When the computed t-value is compared with the tabulated one, which equals 1.96 , it is apparent that the computed one is greater than the tabulated. Moreover, when the computed coefficient of significance is compared with the predetermined one, which equals 0.05 (1-0.95), it is apparent that the computed one is lower. Because the computed t-value is greater than the tabulated, and because the computed coefficient of significance is lower than the predetermined one, the null hypothesis is rejected, while the alternative one is accepted. In more details, the test of this hypothesis reveals that auditors' ability to detect the practices of creative accounting is influenced by their application to contingent fees, commission determination, rights of advertising, and organization form and name. Regarding the coefficients of correlation and determination, table 12 shows that $r$ equals 0.993 , and $r^{2}$ equals 0.985 , which means a strong correlation is available between these ethical values and auditors' ability to detect the practices of creative accounting. Moreover, this information means that a large portion of change in auditors' ability to detect the practices of creative accounting is attributed to the ethical values involved in this hypothesis. 
Table 12. Related statistics to the effect of contingent fees, rights of advertising, organization form, and name on auditors' ability to detect creative accounting practices

\begin{tabular}{cccccc}
\hline T-value & $\mathbf{R}$ & $\mathbf{R}^{2}$ & Degrees of Freedom & B & Significance \\
\hline 97.177 & 0.993 & 0.985 & 141 & 23.953 & 0.000 \\
\hline
\end{tabular}

Based on available statistics in table 12, the regression model regarding the effect of contingent fees, rights of advertising, commission determination, and the use of organization form and name from one side, and auditor's ability regarding their ability to detect the practices of creative accounting is as follows:

$$
C A D=4.387+23.95 D R+e
$$

\subsubsection{The Fourth Hypothesis}

$\mathrm{Ho}_{4}$ : All ethical aspects of audit profession do not affect auditors' ability to detect creative accounting practices.

All items included in the last three sections of the questionnaire were used in measuring whether auditors follow the ethics of their profession or not. Therefore, the effect of all ethical aspects was used to identify the influence of the different ethical rules of audit profession on auditors' ability to detect the practices of creative accounting.

It was previously mentioned that the multiple-linear regression method is used in testing this hypothesis, based on f-test under 95 percent level of confidence. Table number 13 shows that the computed f-value equals 98.35 , and the coefficient of significance equals zero, or much closed value to zero. When the computed f-vale is compared with the tabulated one which equals 1.96 , we find that the computed one is greater than the tabulated. Moreover, when the computed coefficient of significance is compared with the predetermined one, which equals $0.05(1-0.95)$, it is apparent the computed one is lower. Because the computed f-value is greater than the tabulated, and because the computed coefficient of significance is lower than the predetermined one, the null hypothesis is rejected, while the alternative one is accepted. In more details, the test reveals that the different ethical aspects of audit profession affect auditors' ability to detect the practices of creative accounting.

Considering the coefficient of correlation (R), it is clear that there is a strong correlation between the entire rules of audit ethics, and the ability of auditors to detect the practices of creative accounting. In addition, because the coefficient of determination is also high, we find that audit ethics play an important role in detecting creative accounting practices, and determine a large portion of auditors' ability in the detection of these practices.

Table 13. Related statistics to the effect of all ethical rules on auditors' ability to detect creative accounting practices

\begin{tabular}{|c|c|c|c|c|c|}
\hline F-value & $\mathbf{R}$ & $\mathbf{R}^{2}$ & Degrees of Freedom & B & Significance \\
\hline 98.35 & 0.993 & 0.986 & 141 & 21.320 & 0.000 \\
\hline
\end{tabular}

Based on statistics appear in table 13, the regression model that represents the effect of the entire rules of audit ethics on auditors' ability to detect the practices of creative accounting is as follows:

$$
C A D=2.279+0.0594 I+0.683 O+23.776 D R+e
$$

\section{Conclusion}

Based on the previous section which presents the analysis of data and hypotheses testing, the study finds that auditors' ability to detect the practices of creative accounting is affected by the different rules of the audit ethics. In brief, the study finds that auditors' independency affects in practice auditors' ability to detect the practices of creative accounting. In other words, as auditors' ability increases, as their ability to detect the practices of creative accounting is also increase.

The second conclusion of the study is that auditors' ability to detect creative accounting practices is affected by their integrity and objectivity. The study reveals that as auditors have more integrity and they are more objective, 
as their ability to detect the creative accounting practices increases.

The third conclusion of the current study is that auditors' ability to detect the practices of creative accounting practices is influenced by other aspects or rules of audit ethics. The study shows that auditors' ability in the detection of creative accounting practices is influenced by contingent fees, rights of advertising, organization form, and name. The study shows that these four rules of auditors' ethics affect their ability to detect the practices of creative accounting more than their independency, integrity, and objectivity.

The last conclusion is that all aspects and rules of audit ethics affect, in different strengths, auditors' in practice ability to detect the practices of creative accounting. In more details, this study finds that auditor's ability to detect the practices of creative accounting is affected by the entire group of audit ethics.

\section{References}

Amat, B., \& Dowds. (1999). The Ethics of Creative Accounting. Working Paper. Central Lancashire University: England and Massey University: New Zealand.

Bolkaou, A. R. (2004). Accounting Theory (5th ed.). Thompson Learn.

Cromier. (2006). The Auditor's Assessment and Detection of Corporate fraud: Some Canadian Evidence. International Journal of Accounting, 3, 133-165.

Dahdouh, H. (2006). The Responsibility of Auditors Towards Detecting Fraudulent in the Financial Reports of Industrial Companies and the factors Affecting this Detection. University of Damascus Journal, 22(1).

Marianne, O. (2006). Audit Independence: Its Importance to the External Auditor's Role in Banking Regulation and Supervision. Retrieved from http://mpra.ub.uni-muenchen.de/231/

Marks, B. (2009). Ethics and Governance: Evolving responsibilities for audit committees resulting from the credit crunch. Working Paper, University of Johannesburg.

Matar, M., \& Al Halabi, L. (2009). The Role of External Auditors in Restricting the Effects of Creative Accounting on the Credibility of Financial Data Issued by the Jordanian Shareholding Companies. Master Thesis, Middle East University.

Moldovan, R., Achim, S., \& Avram, C. (2010). Fighting the Enemy of Fair View Principle-Getting to Know Creative Accounting. Stiinte Economice.

Naser, K. (1993). Creative Financial Accounting: Its Nature and Use. Hemel Hempstead: Prentice Hall.

Posner, R. (1974). Theories of economic regulation' 5 Bell. Journal of Economics and Management Science, 335-358. http://dx.doi.org/10.2307/3003113

Rabin, C. E. (2005). Determinants of Auditors' Attitudes Towards Creative accounting. Meditari Accountancy Research, 13(2), 67-88. http://dx.doi.org/10.1108/10222529200500013

Vladu, A., \& Matis, D. (2010). Corporate Governance and Creative Accounting: Two Concepts Strongly Connected? Some Interesting Insights Highlighted by Constructing the Internal History of a literature. Annales Universitatis Apulensis Series Oeconomica, 12(1).

\section{Questionnaire}

Dear auditor:

Please be informed that the researchers attempt to examine the role of audit ethics in detecting and prevention of creative accounting practices. Therefore, this questionnaire is directed towards the practitioners of audit in Jordan. Because you are selected to be one among the study sample, and because you have the required, please answer the items of this questionnaire.

The researcher promise you that the data you provide will not be used for other than the purposes of this study, and it will be subject to secret treatment. Before end, the researchers are pleasant to thank you for the data you provide, and for the time you consume in the process of the questionnaire answering.

Warm Regards

The Research Team 


\section{Section 1}

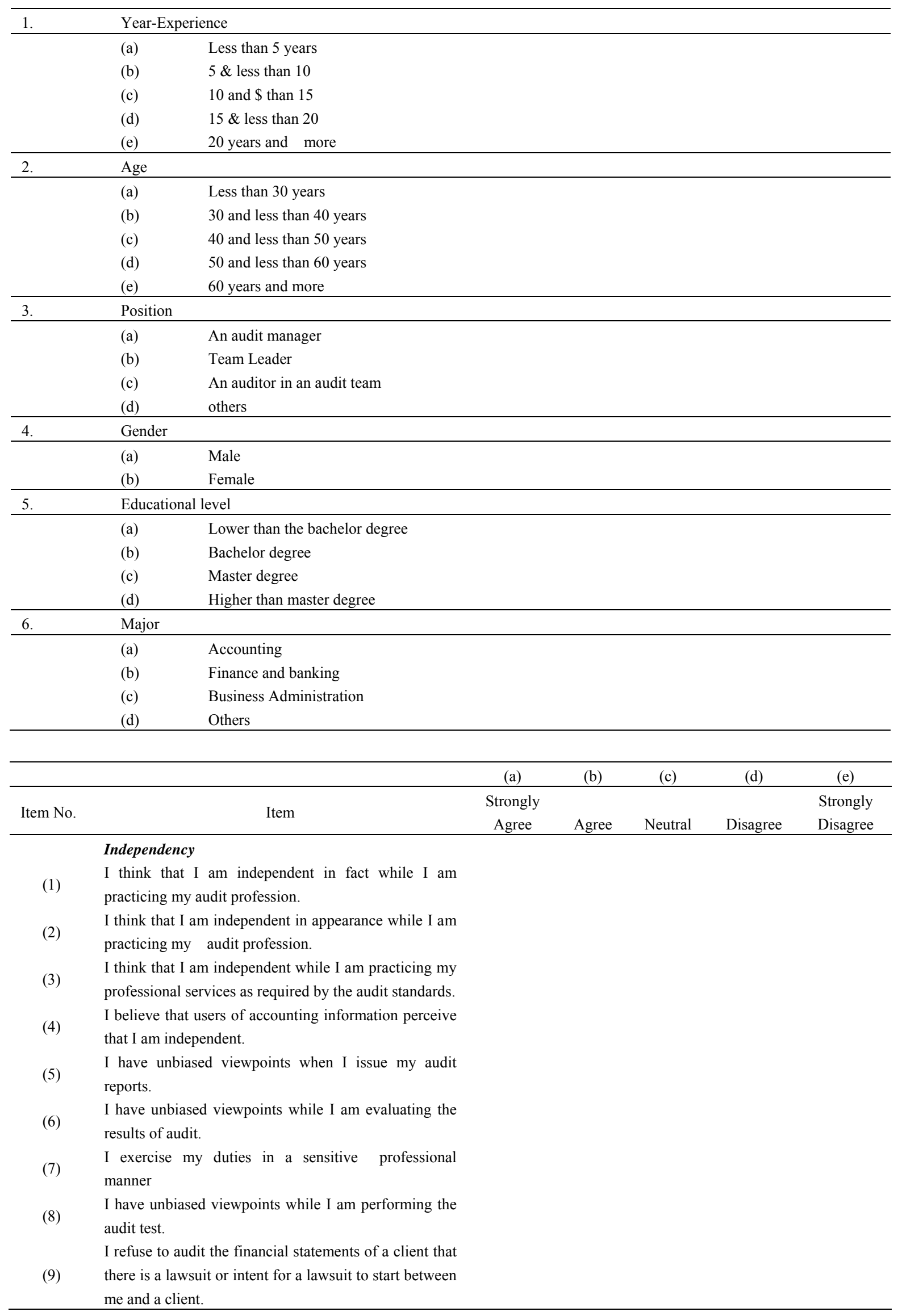


I don't perform audit activities for a client that I am a

(10) director, officer, manager, or employee in the client firm.

I don't accept the performance of an audit duties for a

(11) client that I have an ownership of joint investor or investee relations with that client.

(12) I don't audit the statements of a client that I have loans from the client 's firm.

(13) I don't audit statements of a client when my family has financial interests in that client.

(14) I don't audit the statements of a client that I have material indirect investments in that client.

(15) I do not accept the audit of a client's statements when I have some financial interests in that client.

(16) I don't accept to audit the client's statements when I have stocks in that client.

(17) I am able to maintain an unbiased attitude throughout the audit in practice.

\section{Integrity and objectivity}

I maintain integrity while I am performing my audit duties.

I am free of conflict of interests while I am performing my audit duties.

I don't knowingly misrepresent facts or subordinate my

(3) judgment to others while I am performing my audit duties.

(4) I attempt to be objective while I am practicing my audit duties.

(5) I feel that I am free of conflict of interest in discharging my professional responsibilities I perform my professional responsibilities with the highest sense of integrity

(7) I attempt to maintain objectivity in all of my duties.

(8) I am able to take unbiased viewpoint in the performance of my audit.

(9) I feel that I am in practice able to take unbiased viewpoint in the evaluation of results.

(10) I attempt to maintain integrity in all of my duties.

(11) I am free of conflict of interests

\section{Other Ethical Issues}

When I am in public practice, I don't perform for a

(1) contingent fee any professional services if I perform for the same client an audit activities.

When I am in public practice, I don't perform for a

(2) contingent fee, any professional services if I perform for the same client a review.

When I am in public practice, I don't perform for a

(3) contingent fee any professional services if I perform for the same client certain compilation of financial statements.

When I am in public practice, I don't perform for a contingent fee any professional services if I perform for the same client an examination of prospective financial statements. When I am in practice, I don't seek to obtain clients by advertising and other forms of solicitation in a false 
manner.

(6) When I am in practice, I don't seek to obtain clients by other forms of solicitation in a misleading manner.

When I am in practice, I don't seek to obtain clients by

(7) advertising and other forms of solicitation in a deceptive manner.

When I am in practice, I don't receive or pay a

(8) commission or referral fee for any client if I perform for the client an audit.

When I am in practice, I don't receive or pay a commission or referral fee for any client if I perform for the client a review, or certain compilation of financial statements.

When I am in practice, I don't receive or pay a commission or referral fee for any client if I perform for the client an examination of prospective financial statements.

(11) When I am in practice, I perform my profession in an allowed form of organization

When I am in practice, I don't practice public accounting under a misleading name.

\section{Creative Accounting}

I feel that I am able to detect the sale of assets at higher

(1) prices than its book value in a selected periods, just to affect the client's profits

(2) I feel that I am able to detect the artificial entries to affect profits in selected accounting periods.

(3) I believe that I am able to detect the sale of an asset and lease it again to increase profits

(4) I feel that I am able to identify any transfer of profits from period to period.

I perceive that managements have incentives to practice creative accounting.

(6) I feel that I have the abilities to detect the transfer of transactions from period to period.

(7) I think that I have the abilities to detect the selection of a selected accounting method to maximize profits.

(8) I perceive that managements have several incentives to manipulate its revenues.

I have the ability to detect the creative accounting

(9) procedures that have been taken to capitalize noncapitalizable expenses.

I perceive that managements may record nonfactual revenues

(11) I am able to detect any overvalued inventory.

(12) I am able to detect any manipulation of provisions.

(13) I perceive any undervalued bad debts.

(14) I can detect that managements did not record any decrease in the prices of assets.

Auditors have the abilities to identify that disclosure do not cover some events.

(16) Auditors can detect any overvalued intangible assets. I think that I can detect that the client did not apply the principle of historical cost where it should be used.

I have the required ability to identify that the

(18) management did not disclose the items of restricted 
cash.

(19)

I can detect any change in the used accounting methods of long-term investments

(20) I think that I can detect that managements recognized uninsured litigations.

(21) I can detect that the management does not classify the payable part of long-term loans under short-term loans.

(22) I can detect that a revenue is recognized while the sale transaction is still incomplete.

I perceive that managements have the incentives to

(23) transfer a specific expense from a current to future period.

I perceive that managements may classify some

(24) operating cash flows under investing or financing activities.

I perceive that managements may remove a nonrecurring item.

\section{Copyrights}

Copyright for this article is retained by the author(s), with first publication rights granted to the journal.

This is an open-access article distributed under the terms and conditions of the Creative Commons Attribution license (http://creativecommons.org/licenses/by/3.0/). 